\title{
The Regulations of the Local Sea Fisheries Committees in England and Wales.
}

\author{
By
}

E. J. Allen, B.Sc., Director of the Plymouth Laboratory.

The powers conferred on the Board of Trade, under the Sea Fisheries Regulation Act of 1888, to create, upon the application of a County or Borough Council, a local Fisheries District, and to provide for the constitution of a Local Fisheries Committee for the regulation of the sea fisheries carried on within the district, have been requisitioned by the majority of the Councils of the maritime counties of England and Wales, and at the present time Fisheries Districts and Fisheries Committees are constituted around nearly the whole coast line, the Committees having jurisdiction over all fishing carried on within the three-mile limit. The only portion of coast still unprovided for is that which lies in the counties of Norfolk and Suffolk, between Happisburg and Dovercourt.

The following is a list of the Fisheries Districts, with their boundaries, as they now exist:-

Northumberland-from the boundary between England and Scotland to the river Tyne.

North-EAStern-from the river Tyne to Donna Nook Beacon, on the coast of Lincolnshire.

EAstern-from Donna Nook Beacon to Happisburg, on the coast of Norfolk.

Between Happisburg in Norfolk and Dovercourt in Essex no Fisheries District has been established.

Kent and Essex-from Dovercourt in Essex to Dungeness.

Sussex-from Dungeness to Hayling Island.

Southern-from Hayling Island to the western boundary of Dorset. 
Devon-Southern section, from eastern boundary of Devon to Rame Head in Cornwall. Northern section, from eastern to western boundary of Devon.

CoRnwalL-from northern boundary of Cornwall to Rame Head.

Glamorgan-from Nash Point to Worms Head.

Milford Haven - from Worms Head to Cemmaes Head in Pembroke.

Western-from Cemmaes Head to the boundary between Carnarvon and Denbigh.

LANCASHIRE-from the boundary between Carnarvon and Denbigh to Haverigg Point in Lancashire.

Cumberland-from Haverigg Point to Sark Foot.

The powers of the Local Fisheries Committees, as extended by subsequent Acts (Fisheries Act, 1891, and Sea Fisheries [Shell Fish] Regulation Act, 1894), include the making of bye-laws, subject to the approval of the Board of Trade, for the prohibition or regulation of any method of fishing for sea fish, for the establishment of close seasons for any sea fish, and for the regulation, protection, and development of fisheries for all kinds of shell fish (molluscs and crustaceans). Those powers have been largely exercised by the Committees, and the full text of all the bye-laws, which have received the sanction of the Board of Trade, is published in the Annual Reports of the Inspector's of S'ea Fisheries for England and Wales.

It may be useful to those interested in the protection of fisheries, more especially of inshore fisheries, to bring together under subject headings the regulations now in force, which vary considerably in the different districts around the coast. The regulations and restrictions apply to the sea within three miles of the coast, but not to those tidal estuaries which are under the jurisdiction of Boards of Salmon Conservators.

\section{Trawling with Steam Vessels.}

Trawling from vessels propelled otherwise than by sails or oars is entirely prohibited on the east coast of England, from Northumberland to the southern limit of the Eastern Fisheries District at Happisburg, on the coast of Norfolk. South of this point steam trawling is permitted along the east coast, and along the south coast of Sussex as far westward as Hayling Island, the mesh of the trawl, however, being regulated, as for sailing trawlers (see below), within the limits of the Kent and Essex and the Sussex Sea Fisheries Districts.

Along the remainder of the south coast (Southern, Devon, and Cornwall Districts), and along the west coast of England and Wales, steam trawling is forbidden, excepting in the Milford Haven and Cumberland Districts, 


\section{Trawling with Sailing Vessels.}

\section{Trawling for Sea Fish.}

Northumberland District.-Trawling is prohibited.

North-eastern District (Durham and Yorteshire).-Probibited, excepting in Bridlington Bay, between February 1st and September 1st; beam not to exceed $22 \mathrm{ft}$., and net to be raised and cleared at least every half-hour.

Eastern District (Lincolnshire and north coast of Norfoll).In northern portion of district,* the length of trawl beam must not exceed $22 \mathrm{ft}$., and the net must be raised and cleared not less than once in every hour.

In southern portion of district † trawling is prohibited.

Norfolk (east coast) and Suffolk.-No district, and therefore no restrictions.

Kent and Essex District.-No trawl net may be used having more than 36 rows of knots to the linear yard.

Sussex Districr.-No trawl net may be used having more than 30 rows of knots to the yard.

Southern District (Hants and Dorset).-No restrictions.

Devon District.-Trawling is prohibited in the bays on the south coast. On the north coast there are no restrictions.

Cornwall District.-No restrictions.

Glamorgan District (south coast of Wales). Mesh-not less than $1 \frac{1}{2}$ inch gauge. $\neq$ Circumference of net-not less than 100 meshes. Beam-not greater than 40 feet.

Milford Haven District.-No restrictions.

Western District (west coast of Wales).

Mesh-not less than $1 \frac{1}{2}$ inch gauge.

Circumference of net-not less than 100 meshes.

Beam-not greater than 45 feet.

* "That portion of the said district which lies to the westward of a line drawn true north-east from the lightship known as the 'Lynn Well Light,' and to the northward of a straight line drawn from Gibraltar Point to Gore Point."

$\uparrow$ "That portion of the said district which lies between a line drawn true northnorth-east from the building standing upon Salthouse Beach, known as Randall's Folly (or the Sailor's Refuge), and a line drawn true north-east from Cromer Lighthouse."

‡"No person shall use any trawl net for taking sea fish, other than shrimps or prawns, having a mesh through which a square gauge of $1 \frac{1}{2}$ inches measured across each side of the square, or 6 inches measured round the four sides, will not pass without pressure when the net is wet." 


\section{Lancashire District.}

Mesh-not less than $1 \frac{3}{4}$ inch gauge.

[Except south of Formby Point, from July 1st to October 15th, mesh not less than $1 \frac{1}{2}$ inch gauge may be used.]

Circumference of net-

With beam greater than $25 \mathrm{ft}$, circumference not less than 80 meshes.

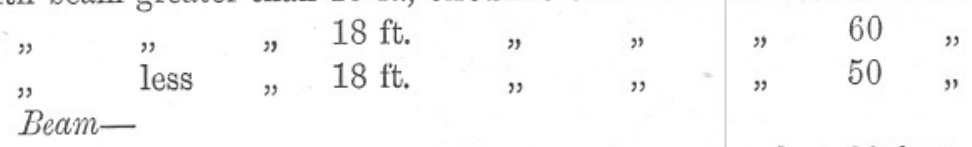

From January 1st to June 30th not to be greater than 30 feet.

Vessel-

From January 1st to June 30th not to be greater than 15 tons.

Cumberland District.-No restrictions.

\section{Shrimps and Prawns.}

(All regulations applying to fishing for shrimps and prawns, whether by trawling or other means, will be included under this heading.)

Northumberland District.-Trawling prohibited.

Nokth-Eastern District (Durham and Yorkshire to Donna Nook). - Beam not to exceed 8 feet in extreme length, and net to be raised and cleared at least once in every half-hour.

Excepting:-(1) Between a straight line drawn true east from Castle Eden Dene, and a straight line drawn true north-east from Skinningrove Beck, a push net only may be used.

(2) In the River Humber, between a straight line drawn from the entrance to St. Andrew's Dock to the northern extremity of the pier at New Holland, and a straight line drawn from Spurn Head Lighthouse to Donna Nook Beacon, between March 1st and October 31st, a trawl having a beam not exceeding 20 feet may be used, the net to be raised and cleared not less than once in every hour.

EAstern District (Lincolnshire and north coast of Norfolk).Length of trawl beam not to exceed 20 feet, and net not to have any pocket. Between December 1st and the last day of February no trawl net may be used for taking shrimps or prawns.

East coast of Norfolk and Suffolk.-No district, and therefore no restrictions.

Kent and Essex District.--No trawl net may be used having more than 108 rows of knots to the linear yard, except that for a length of 8 feet from the cod end there may be not more than 144 rows of knots to the yard.

Sussex District.-No restrictions.

Southern District (Hants and Dorset).--No restrictions. 
Devon District.-Trawling in the bays on the south coast is prohibited, with the exception of trawling for shrimps or prawns in Plymouth Sound, with a beam not exceeding 8 feet in length, the net to be raised and cleared at least once every half-hour.

Connwall District.-No restrictions.

Glamorgan District (south coast of Wales).

Mesh-not less than $\frac{3}{8}$ inch gauge.*

Circunference of net-not less than 160 meshes.

Beam-not greater than 40 feet.

Milford Haven District.-No restrictions.

Western District (west coast of Wales).

Mesh-not less than $\frac{3}{8}$ inch gauge.

Circumference of net-not less than 160 meshes.

Beam-not greater than 45 feet.

Lancashike District.

Mesh-not less than $\frac{3}{8}$ inch gauge.

Circumference of net-

With beam greater than $20 \mathrm{ft}$., not less than 140 meshes.

" " less " $20 \mathrm{ft}$. " , 120 ,

Beam-not greater than 25 feet.

Cumberland District.-No restrictions.

\section{Seining.}

In the North-eastern (Yorkshire and Lincolnshire), Western (west coast of Wales), and Lancashire Districts seining is prohibited, excepting for the capture of sand-eels for bait in the North-eastern, and for herring, mackerel, and sparling in the Western and Lancashire Districts. In these cases also the net is regulated.

In the Kent and Essex, Sussex, and Glamorgan Districts there are general mesh regulations for all nets used in the capture of sea fish, which would include seines.

In other districts there are no regulations.

The following regulations in the above-named districts may be mentioned :-

North-Eastern District.-A net may be used for taking sand-eels for bait, without a pocket; net 108 feet long and 12 feet deep, the central portion (12 ft. $\times 12 \mathrm{ft}$.) to be of closely-textured netting.

* "No person shall use any net for taking shrimps or prawns having a mesh through which a square gauge of three-eighths of an inch measured across each side of the square, or $1 \frac{1}{2}$ inches measured round the four sides, will not pass without pressure when the net is wet." 
Kent and Essex District.-No net may be used for sea fish having more than 144 rows of knots to the yard.

Sussex District.-No seine or draft net may be used having more than 30 rows of knots to the yard, excepting when fishing for herring or mackerel, at any time, or for sprats during November, December, and January.

GLamorgan District.-No net for sea fish (except sprats) may have a mesh less than 1 inch gauge.

Western District (west coast of Wales). - No net for taking mackerel or herring may have mesh less than 1 inch gauge.

Lancashire District.-Similar to Western District.

\section{Trammel, Stake, and Stop Nets.}

On the east coast the only bye-law relating to such nets is one made by the North-eastern Committee, whereby the use of trammel nets is prohibited in certain specified districts off the mouths of the principal rivers. On other parts of this coast the use of these nets is unrestricted.*

On the south coast the only regulation applies to Chichester Harbour, where no stop nets may be set across the creeks within one hour before and after low water.

On the west coast regulations exist in the Glamorgan, Western, and Lancashire Districts only, as follows :-

Glamorgan District (south coast of Wales). - Stop nets for sprats must have a mesh not less than $\frac{9}{16}$ inch gauge. All stake and stop nets must be marked by buoys or poles, must be at least 10 yards from other stake nets or any fishing weir, and a pool 12 inches deep at low water must be kept for each net from May to October, at other times 6 inches deep, such pool to be threequarters the size of the cage of the net, and not less than 36 square feet in area.

Western District (west coast of Wales). - Trammel nets are prohibited. The position of stake nets must be marked by poles or buoys: the nets must not be nearer the centre of any stream than the edge of the stream at low water, and they must not be nearer than 50 yards to any other stake net.

* In this connection particular notice should be taken of the fact that we are not considering any bye-laws applicable to estuaries under the jurisdiction of Boards of Salmon Couservators. 
Lancashire Districr.-Trammel nets are prohibited. The regulations for stake nets are generally similar to those in force in the Western District, but the distance from other stake nets must be 150 yards. There is also a somewhat curious bye-law, which reads as follows:- "No person shall use, in fishing for mackerel or herring, any stake net except at the times and places at which, and in the manner in which, such nets have been heretofore commonly used for the capture of such fish respectively."

\section{Smelt or Sparling.}

In the Northumberland District there are no restrictions. In the North-eastern sparling nets may be used only between July 21st and March 21st, and mesh of net must not be less than six-tenths of an inch from knot to knot.*

In the Eastern District the nets must have not more than 24 knots to the foot, and they may not be used between April 1st and August 31st.

In the Kent and Essex District the net must have not more than 72 rows of knots to the yard, and must not be more than 60 fathoms long.

On the south coasts of England and Wales there are no restrictions.

In the Western District (west coast of Wales) the mesh of the net must allow a square gauge with each side $\frac{3}{4}$ inch long to pass through, whilst in Lancashire the fish may only be taken with seine or draft net, the size of mesh is increased to one inch, and the fish may not be caught between April 1st and October 31st.

\section{Crabs and Lobsters.}

In considering the regulations relating to crabs and lobsters, it must be borne in mind that the Fisheries (Oyster, Crab, and Lobster) Act, 1877, applies to the whole country, and makes it illegal to take, have in possession, sell or expose for sale, any edible crab which measures less than $4 \frac{1}{4}$ inches across the broadest part of the back (except when for use as bait); or any edible crab carrying spawn attached to the tail; or any edible crab which has recently cast its shell; or any lobster which measures less than eight inches from the tip of the beak to the end of the tail, when spread out flat.

The Sea Fisheries Committees have made the following additional regulations in their respective districts :-

Northumberland District.-No additional restrictions.

* There is also a restriction as to the nature of the material of which the net is made. 
NoRTH-EAstern District (Durham and Yorkshire).-Crabs under $4 \frac{1}{4}$ inches not to be taken, even for bait. Lobsters under 9 inches long not to be taken. No lobsters or crabs to be taken between September 1st and January 31st of following year.

EAstern District (Lincolnshire and north coast of Norfolk).-Crabs under $4 \frac{1}{4}$ inches not to be taken, even for bait.

No lobster carrying spawn, and no lobster which has recently cast its shell and is still soft, to be taken. From November 1st to June 30th no crabs known locally as "whitefooted" to be taken.

Kent and Essex District.-No lobster carrying spawn to be taken.

Sussex, Southern (Hants and Dorset), And Devon Districts.-No restrictions.

Cornwall District.-No male edible crab less than 6 inches broad, may be taken.

" female ",$\quad 5$

Glamorgan and Milford Districts.-No restrictions.

$\begin{aligned} & \text { Western District (west coast of Wales) } \\ & \text { Lancashire District } . \quad . \\ & .\end{aligned} .\left\{\begin{array}{l}\text { No lobsters or crabs } \\ \text { carrying spawn may } \\ \text { be taken. }\end{array}\right.$

No lobster less than 9 inches from beak to tail; no edible crab less than 5 inches across broadest part of back, may be taken.

Cumberland District.-No restrictions.

\section{Molluscs.}

Oysters.-In addition to the close times fixed by Act of Parliament, viz., for deep-sea oysters from 15th June to 4th August, and for all other oysters from 14th May to 4th August, the following are the regulations made by Local Fisheries Committees for their respective districts :-

Kent and Essex District.-No cultch may be removed from an oyster 'ground.

Sodthern District (Hants and Dorset).-No oysters may be taken from 15th May to 30th September, and none may be taken at any time which will pass through a circular ring of 2 inches in internal diameter, except for stocking and breeding purposes.

No cultch or other material for the reception of spat may be

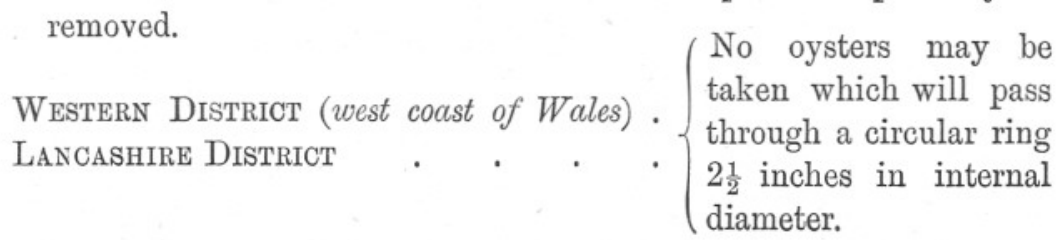

In other districts no additional restrictions have been made. 
Mussels. - Eastern District (Lincolnshire and north coast of Norfolk). - No mussels may be taken from May 1st to August 31st, nor any less than 2 inches in length at other times, except for stocking or breeding.

No instrument may be used for taking mussels other than a rake not exceeding 18 inches broad, and with the teeth 1 inch apart.

Glamorgan District (south coast of Wales).-No mussels may be taken in May, June, or July, except for stocking or breeding purposes.

Mussels may be taken only (a) with a dredge, $(b)$ by hand, or (c) with a rake not more than 3 feet wide, with the teeth 1 inch apart.

Western District (west coast of Wales).-No mussels may be taken in May, June, July, or August, excepting for stocking, breeding, or bait (in one part of the district the prohibition extends also to April, September, and October), and none may be taken at any time less than $2 \frac{1}{4}$ inches long.

Mussels may be taken only $(a)$ by hand, $(b)$ with a rake not exceeding 3 feet wide, used from a boat, and when the bed is covered with at least 4 feet of water.

Lancashire District.-No mussels may be taken in May, June, July, or August, and none at any time less than $2 \frac{1}{4}$ inches long.

Mussels may be taken only $(a)$ by hand, $(b)$ with a rake not exceeding 3 feet wide, used only from a boat, and when the bed is covered with at least 4 feet of water.

In other districts no restrictions have been made.

Cockles.--Regulations are in force as follows :-

EAstern District (Lincoln and north coast of Norfolk).-No instrument may be used for taking cockles except a rake not more than 12 inches long, with teeth $\frac{3}{4}$ inch apart.

Glamorgan District (south coast of Wales).-Cockles may only be taken by hand, or with a rake not more than 12 inches wide, with teeth $\frac{3}{4}$ inch apart.

WESTERn District (west coast of Wales).-Cockles may only be taken by hand, or with a rake not more than 12 inches wide, with teeth $\frac{3}{4}$ inch apart. None may be taken which pass through an oblong gauge $\frac{3}{4}$ inch wide and 2 inches long. 
LANCASHIRE District.-No cockles may be taken which pass through an oblong gauge $\frac{3}{4}$ inch broad and 2 inches long. They may be taken only (a) by hand, (b) with a craam having not more than three teeth, $(c)$ with other instruments under regulations which differ in different parts of the district.*

Periwinkles.-In the Sussex District periwinkles may not be taken between April 1st and October 31st, and in the Southern District not between May 1st and August 31st. In other districts no regulations exist.

\section{Injurious Substances.}

Bye-laws prohibiting the deposit or discharge of any solid or liquid substance detrimental to sea fish or sea fishing are in force in the following districts: Kent and Essex, Sussex, Southern, Devon, and Lancashire.

* Bye-law 20. No person shall fish for cockles except-

(a) By hand, or

(b) With an instrument locally known as a craam, having not more than three teeth : provided that-

(1) Between the 1st day of November and the last day of February following, both inclusive, it shall be lawful to use an instrument locally known as the jumbo, not exceeding 4 feet 6 inches in length, 14 inches in width, and 1 inch in thickness, provided that such instrument shall be constructed entirely of wood, and shall not be dragged across the cockle beds or artificially weighted.

(2) In that part of the district which lies to the southward of a line drawn true west from the mark known as "Rossall Landmark," near Fleetwood, it shall be lawful to use a rake not exceeding 12 inches in width.

(3) In that part of the district which lies between a straight line drawn seawards through the north-west sea marks near Formby Point, and a line drawn true west from the western extremity of the southern training wall in the river Ribble or Gut Channel, it shall be lawful to use a spade. 